\title{
Riverine macroinvertebrate responses to chlorine and chlorinated sewage effluents - Acute chlorine tolerances of Baetis harrisoni (Ephemeroptera) from two rivers in KwaZulu-Natal, South Africa
}

\author{
ML Williams, CG Palmer* and AK Gordon \\ Unilever Centre for Environmental Water Quality, Institute for Water Research, Rhodes University, PO Box 94, Grahamstown 6140, \\ South Africa
}

\begin{abstract}
Chlorine is widely used in South African sewage treatment works, and despite its volatility is likely to have a considerable impact on riverine ecosystems. This paper considers the results of acute $(96 \mathrm{~h})$ toxicity responses to chlorine of riverine mayfly nymphs Baetis harrisoni collected from the small, relatively uncontaminated suburban Westville Stream, KwaZulu-Natal and from the more severely impacted Umbilo River, which flows through the industrial area of Pinetown, KwaZulu-Natal, South Africa. The $96 \mathrm{~h} \mathrm{LC}_{50}$ value for total residual chlorine for nymphs from Westville Stream was $4.1 \mu \mathrm{g} / \mathrm{l}$ and from the Umbilo River $4.8 \mu \mathrm{g} / \mathrm{l}$. This value is well below the general effluent standard of $100 \mu \mathrm{g} / \mathrm{l}$ (General and Special Standards, Regulation 991, 1984), but correlates with the acute effect value guideline of $5 \mu \mathrm{g} / \mathrm{l}$ (South African Water Quality Guidelines, No 7. 1996).
\end{abstract}

Keywords: ecotoxicology, water quality, mayfly

\section{Introduction}

Chlorine is not normally a constituent of natural waters as it is too reactive to persist in the aquatic environment for long (DWAF, 1996). However, large quantities of chlorine constituents are being introduced regularly into receiving waters (Johnson and Jolley, 1990; White, 1992). This is a consequence of the use of chlorine as an oxidizing agent and disinfectant in water purification and wastewater treatment; a control for fouling organisms in industrial cooling towers; and as a constituent of pulp and paper mill effluent. The presence of chlorine in natural waters can have potentially severe consequences for riverine flora and fauna (Dallas and Day, 1993).

To date, chlorine toxicity research has focused mainly on fouling organisms in industrial cooling water systems (Mattice and Zittel, 1976; Doherty et al., 1986; Rajagopal et al., 1997; Rajagopal et al., 2002; 2003) and the effects of paper mill effluent on a number of different organisms (Middaugh et al., 1997; Van den Heuvel et al., 2002). Besides experiments involving Daphnia (Taylor, 1993; Fisher et al., 1999) there appears to have been little research investigating the effect of chlorine toxicity on freshwater invertebrates (Arthur, 1975 and Gregg, 1975 cited in US EPA, 1984; Ward and Graeve, 1978, 1980), and none on South African indigenous riverine invertebrates.

The South African Water Quality Guidelines for Aquatic Ecosystems specifies an Acute Effect Value (AEV) of $5 \mu \mathrm{g} / \mathrm{l}$ for chlorine. These guidelines were, however, developed using international data and in the case of chlorine it is noted that the data used did not satisfy the minimum acute database requirement (DWAF, 1986). It is of interest then to refine the Water Quality Guidelines

\footnotetext{
* To whom all correspondence should be addressed.

용 +2746 622 2428; fax: +2746 622 9427; e-mail: Tally@iwr.ru.ac.za Received 17 September 1998; accepted in revised form September 2003.
}

to reflect actual tolerances of indigenous organisms within the local environment. The aim of this study as a whole was to investigate the effects of chlorinated, treated sewage effluent on riverine macroinvertebrates. To carry out these investigations, both toxicological (this paper) and ecotoxicological (Palmer et al., 2003) approaches were followed. The toxicological aspect involved the selection of a macroinvertebrate, the mayfly Baetis harrisoni (Barnard), and the determination of its acute $(96 \mathrm{~h}) \mathrm{LC}_{50}$ response value to chlorine. However, wild populations that are constantly exposed to a pollutant may also become resistant, and for this reason $B$. harrisoni nymphs were used from both a relatively unpolluted stream in Westville and from the more severely impacted Umbilo River, both in Durban, KwaZulu-Natal.

\section{Materials and methods}

\section{Description of study sites}

The Westville Stream is located in the residential area of Westville, Durban, KwaZulu-Natal (Fig. 1). The stream does not flow through any industrial area and shows no indication of industrial pollution. The soil in this area is quite sandy though and there is some percolation from the septic tanks of neighbouring houses (Dickens, 1993). However, the stream's community diversity suggested it was relatively unpolluted, and had a thriving mayfly population.

The Umbilo River rises at the foot of Field's Hill and flows through industrial, commercial and residential areas of Pinetown, then past the Umbilo Wastewater Treatment Works and the residential areas of Queensburgh and Umbilo, before flowing into the Umbilo Canal which leads into the Durban Harbour, KwaZuluNatal (Fig. 1). The water quality of the river is monitored by staff from the Umbilo Wastewater Treatment Works and is considered poor, with the main impact being caused by industrial effluent and to a lesser extent wastewater treatment effluent. 


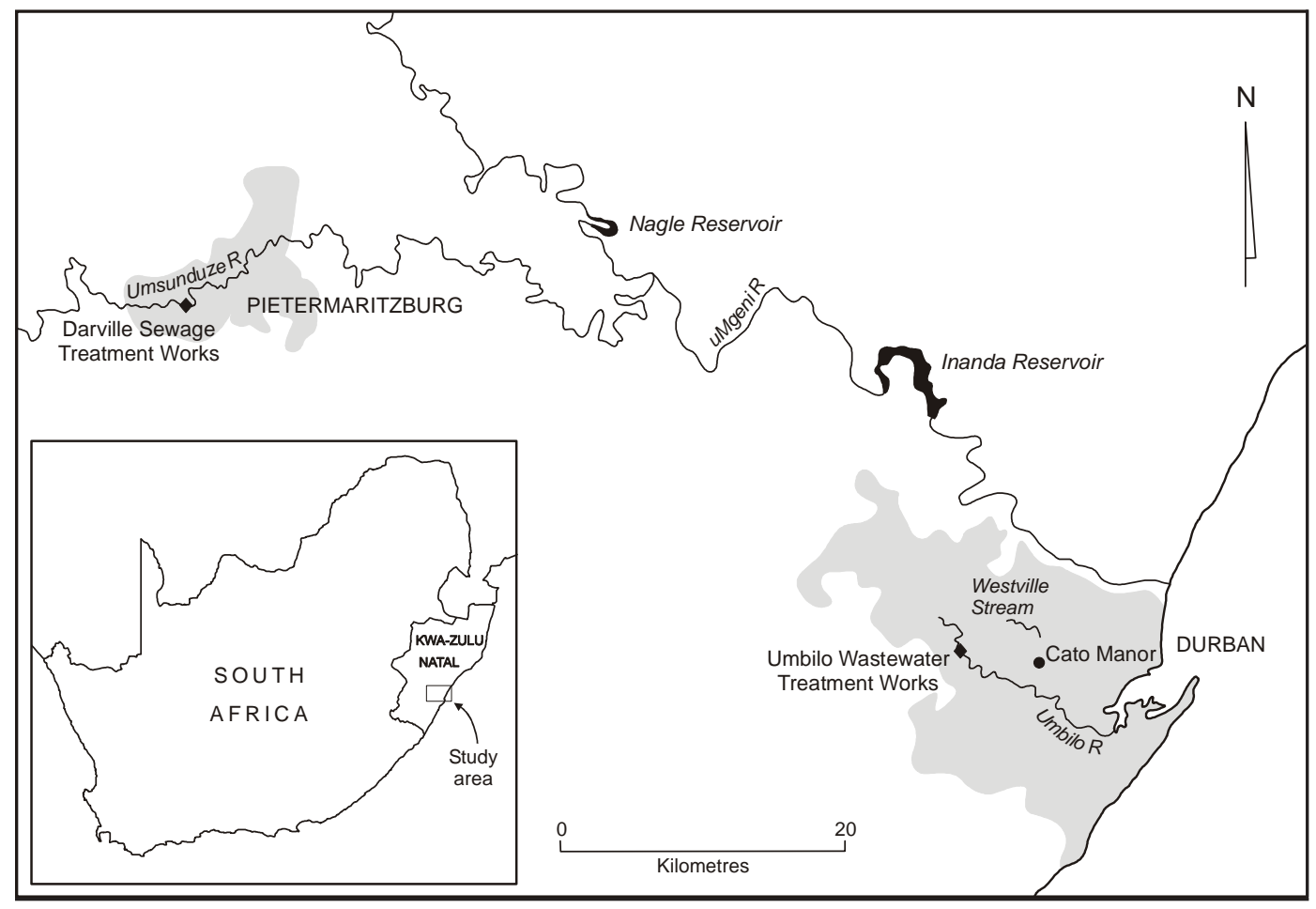

Figure 1

Map of the study area, KwaZuluNatal, South Africa

\section{The flow-through artificial stream for acute chlorine toxicity testing}

Artificial streams can be defined as constructed channels having a controlled flow of water which is used to study some physical, chemical, or biological property of natural streams (Lamberti and Steinman, 1993). Trials by Williams (1996) showed that a recirculating stream was not suitable for testing a volatile chemical such as chlorine, and a flow-through artificial stream system was developed and set up at the Process Evaluation Laboratory at the Wiggins Waterworks in the Cato Manor area near Durban, KwaZuluNatal (Fig. 1). "Dexion" shelving was used to build a stand suitable for supporting the artificial streams and from which the dosing bags could be hung. A length of gutter with a downpipe was attached to the front of the stand to collect the wastewater and convey it to a drain in the floor below.

Each stream channel comprised a $1 \mathrm{~m}$ length of white PVC flatbottomed guttering. In cross section the stream channel was trapezoidal in shape with a base $91 \mathrm{~mm}$ wide, sides $70 \mathrm{~mm}$ high, sloping outwards so that the top of the guttering was $120 \mathrm{~mm}$ wide. A $12 \mathrm{~mm}$ hole was drilled in the "upstream" stop-end to allow the insertion of a $2 \mathrm{~m}$ length of clear plastic tubing connected to a pump submersed in the sump below. A $20 \mathrm{~mm}$ diameter hole was cut in the "downstream" stop-end to allow an even flow out of the stream channel. The hole was covered with $0.6 \mathrm{~mm}$ stainless steel mesh, which was sealed around the sides with silicon sealent, to prevent the escape of test organisms. The stream channel was placed at an angle of $5^{\circ}$ so that there was a region of shallow, fast-flowing water at the head of the stream and a region of deeper, slower water at the outlet.

Incoming raw water from either the Nagle or Inanda reservoirs was drawn off and directed into a 500 I fibreglass sump tank positioned below the artificial stream stand. A large float valve was attached to the inlet of the tank to ensure the maintenance of a constant water level. The water was not heated and the temperature fluctuated between $23^{\circ} \mathrm{C}$ in summer and $13^{\circ} \mathrm{C}$ in winter. Com- pressed air was bubbled through the water to increase the levels of dissolved oxygen to $100 \%$ saturation before use. Water from the sump was pumped to each artificial stream channel using Rena Powerhead C40 submersible pumps. The pumps were positioned $250 \mathrm{~mm}$ below the water level and the outlet tube into the artificial stream above was $600 \mathrm{~mm}$ above water level.

Intravenous drip bags were used to provide a steady flow of sodium hypochlorite and the flow controlled with Baxter CONTROL-A-FLOW regulators (Code 2C 7591). Control valves were set to allow the sodium hypochlorite solution to drip in at the rate of 15 drops per minute. The drip rate was checked a number of times daily for each artificial stream to ensure that a constant rate was maintained. The chlorine concentrations within the drip bags (determined by a specific volume of sodium hypochlorite added to distilled water to make up a volume of $1 \mathrm{I}$ ) and the chlorine levels within the artificial streams were determined using a Lovibond ${ }^{\circledR}$ 2000 Comparator TK 100. The residence time of the chlorine within the artificial streams was not long enough for the reactions leading to combined chlorine forms to occur. As a result free residual chlorine and total residual chlorine values were the same. This paper reports chlorine concentrations as total residual chlorine (TRC), although it is important to note that this value reflects only the free residual chlorine fraction. Drip bags were replaced morning and afternoon with fresh solutions and the outlet mesh was brushed clean twice per day.

\section{Selection of $B$. harrisoni as the test organism}

Various studies have shown that macroinvertebrates are often sensitive to toxicants, and represent a large proportion of the biomass in aquatic systems (Buikema et al., 1982). There are several factors to consider when selecting a test organism, and as there is probably no standard test species that can be used for all ecosystems, the selection will often be based on site-specific considerations (Buikema et al., 1982; Rand and Petrocelli, 1985; Standard Methods, 1992). 
Nymphs of the baetid mayfly, B. harrisoni were selected as test organisms because:

- Macroinvertebrates form a vital link between the organic matter/bacterial/fungal trophic level and fish, and are important in river processes. Baetis harrisoni is a collector/grazerscraper (Palmer et al., 1993), feeding on loose detritus and on benthic attached algae, and is a rheophilous, riffle-dwelling organism well suited to survival in the artificial streams used in the test.

- Baetid spp. have been used for toxicity testing by other researchers and institutions e.g. the United States Environmental Protection Agency (US EPA), the American Society for Testing and Materials (ASTM) (Persoone and Janssen, 1993) and the Institute for Water Research, Grahamstown (Palmer et al., 1996).

- Preliminary sampling in the Umsunduze River in KwazuluNatal revealed that $B$. harrisoni nymphs were present in large numbers upstream of a chlorinated sewage effluent outlet, but absent downstream from the outlet, indicating they were possibly sensitive either to the effluent, or the chlorine, or both.

- Mayflies are found in almost every type of stream as their nymphs occupy a great variety of habitats, and B. harrisoni is widespread and abundant in KwaZulu-Natal (Crass, 1947). At an upstream site in the Umbilo River and in the Westville Stream, they were present in large enough numbers for running several toxicity tests.

The use of B. harrisoni as a test organism could be criticized on the grounds that it is considered to be a relatively tolerant species, found in waters of diverse quality (Chutter, 1994). However, $B$. harrisoni was absent at some sites in the Umsunduze and Umbilo Rivers where water quality was very impaired, so it does represent an indicator of poor water quality. A more intransigent problem is the taxonomic recognition of $B$. harrisoni as a single species. Therefore, specimen samples were lodged at the National Collection, Albany Museum, Grahamstown.

\section{Collection and transfer of test organisms}

Mayfly nymphs were collected using nets made from silk-screen mesh (mesh size $0.15 \mathrm{~mm}$ ). Mayflies were gently rinsed off the net with river water into a $20 \mathrm{I}$ cooler box filled with aerated river water cooled with ice. The transit time to the laboratory was approximately $15 \mathrm{~min}$. Pieces of $10 \mathrm{~mm}$ thick foam rubber were placed into the cooler box to provide a substrate for the mayflies to cling to during transit.

Mayfly nymphs are sensitive to handling, and were gently transferred to the laboratory streams using a white plastic jug. Nymphs were not identified until the end of the experiments, as sampling indicated that usually between 95 and $100 \%$ of mayflies in the stream were $B$. harrisoni. Final stage instar nymphs with dark wing-buds were not used and very small nymphs were also ignored.

\section{Experimental design}

Umbilo mayflies were exposed to three chlorine concentrations $(4,8$ and $12 \mu \mathrm{g} / \mathrm{l})$. The control was replicated in triplicate and each of the chlorine concentrations had 6 replicates, resulting in 21 artificial streams. Westville Stream mayflies were exposed to five chlorine concentrations $(4,6,8,12$ and $16 \mu \mathrm{g} / \mathrm{l})$. The control and each of the chlorine concentrations were replicated in triplicate, resulting in 18 artificial streams.

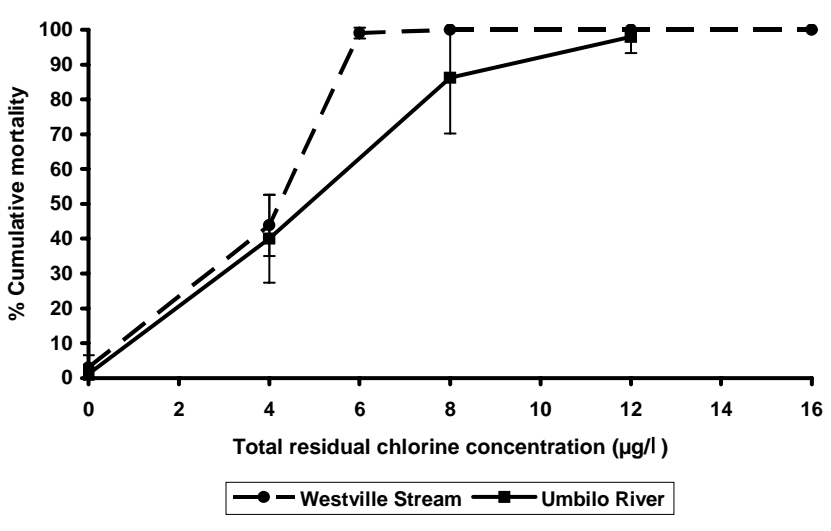

Figure 2

96 h concentration response curves ( \pm standard deviation) for B. harrisoni from the Westville Stream and Umbilo River

\section{Acclimation, testing and data analysis}

The two experiments were conducted during the winter of 1992. Between 35 and 90 nymphs were placed in each artificial stream, and after a $48 \mathrm{~h}$ acclimation period any dead nymphs were removed. Chlorine release was then effected by dripping in the hypochlorite solutions. Mortality was monitored after $2 \mathrm{~h}, 4 \mathrm{~h}, 6 \mathrm{~h}, 8 \mathrm{~h}, 24 \mathrm{~h}, 48$ $\mathrm{h}$ and $96 \mathrm{~h}$ (Standard Methods, 1992). Death is the effect criterion most often used in acute toxicity tests, and may be indicated by lack of response to touch or no movement of antennae, mouthparts or other organs (Parrish, 1985; Standard Methods, 1992). Dead $B$. harrisoni nymphs curl inwards, release their grip on the substrate, and do not respond to touching. Only positively identified $B$. harrisoni nymphs were used in mortality computations. $\mathrm{LC}_{50}$ values were determined using the US EPA Probit Analysis Program Version 1.5 when the data was parametric, and the US EPA Trimmed Spearman-Karber Program Version 1.5 when data was non-parametric (Standard Methods, 1992).

\section{Results}

After $96 \mathrm{~h} \mathrm{~B}$. harrisoni from the control treatments of both the Umbilo River and Westville Stream experiments showed cumulative mortalities below $10 \%$ (Fig. 2). At a TRC concentration of $4 \mu \mathrm{g} / \mathrm{l}$ the $96 \mathrm{~h}$ cumulative mortalities for the Umbilo B. harrisoni were $40 \%$ and for Westville $44 \%$ with standard deviations from both experiments making this difference appear insignificant. Westville $B$. harrisoni experienced $99 \%$ cumulative mortality at $6 \mu \mathrm{g} / \mathrm{l}$, and then $100 \%$ at 8,12 and $16 \mu \mathrm{g} / \mathrm{l}$. Umbilo B. harrisoni showed $86 \%$ mortality at $8 \mu \mathrm{g} / \mathrm{l}$ and $98 \%$ at $12 \mu \mathrm{g} / \mathrm{l}$, with the standard deviations from Umbilo and Westville $B$. harrisoni at both these concentrations overlapping. When considering the $96 \mathrm{~h}$ concentration response curves; that of the Umbilo B. harrisoni falls to the right of B. harrisoni from the Westville Stream (Fig. 2).

The $96 \mathrm{~h}$ cumulative mortality data from both experiments was normally distributed. Consequently a Probit anaysis was conducted and revealed a $\mathrm{LC}_{50}$ value for Umbilo $B$. harrisoni of $4.8 \mu \mathrm{g} / \mathrm{l}$ TRC with upper and lower $95 \%$ confidence limits of $5.1 \mu \mathrm{g} / \mathrm{l}$ and $4.5 \mu \mathrm{g} / \mathrm{l}$. The Westville $B$. harrisoni $\mathrm{LC}_{50}$ value was computed to be $4.1 \mu \mathrm{g} / \mathrm{l}$ TRC with upper and lower $95 \%$ confidence limits of $4.2 \mu \mathrm{g} / \mathrm{l}$ and $3.9 \mu \mathrm{g} / \mathrm{l}$. 


\begin{tabular}{|c|c|c|c|c|}
\hline \multicolumn{5}{|c|}{$\begin{array}{c}\text { TABLE } 1 \\
\text { Chlorine } \mathrm{LC}_{50} \text { values }(\mu \mathrm{g} / \mathrm{l}) \text { reported in the literature }\end{array}$} \\
\hline Reference & Organism & $24 \mathrm{~h} \mathrm{LC}_{50}$ & $48 \mathrm{~h} \mathrm{LC}_{50}$ & $96 \mathrm{~h} \mathrm{LC}_{50}$ \\
\hline Present study & $\begin{array}{l}\text { Baetis harrisoni } \\
\text { Westville Stream } \\
\text { Umbilo River }\end{array}$ & $\begin{array}{l}11.2 \\
10.1\end{array}$ & $\begin{array}{l}5.0 \\
6.5\end{array}$ & $\begin{array}{l}4.1 \\
4.8\end{array}$ \\
\hline Gregg, 1974 & $\begin{array}{l}\text { Centroptilium spp. } \\
\text { Ephemerella lata } \\
\text { Iorn humeralis } \\
\text { Isonychia spp. } \\
\text { Stenonema ithaca }\end{array}$ & $\begin{array}{c}71 \\
46(8 \mathrm{~h}) \\
502(8 \mathrm{~h})\end{array}$ & $\begin{array}{l}27 \\
93\end{array}$ & \\
\hline Arthur et al., 1975 & Pteronarcys spp. & & & 400 \\
\hline Gregg, 1975 & Stenonema ithaca & & & 102 \\
\hline Cairns et al., 1976 & Daphnia magna & 140 & 116 & \\
\hline $\begin{array}{l}\text { Ward and De Graeve, } \\
1978,1980\end{array}$ & $\begin{array}{l}\text { Hexagenia spp. } \\
\text { Daphnia magna } \\
\text { Daphnia magna } \\
\text { (monochloramine) }\end{array}$ & & $\begin{array}{c}357 \\
45 \\
17\end{array}$ & \\
\hline Taylor, 1993 & $\begin{array}{l}\text { Ceriodaphnia dubia } \\
\text { (hypochlorus acid) } \\
\text { (hypochlorite ion) } \\
\text { (monochloramine) } \\
\text { (dichloramine) }\end{array}$ & $\begin{array}{c}5 \\
6 \\
16 \\
27\end{array}$ & & \\
\hline
\end{tabular}

\section{Discussion}

A comparison of the chlorine tolerance of $B$. harrisoni in this study with other macroinvertebrates (Table 1) shows the lack of standardization in the durations of acute toxicity tests. The recommended acute test duration of $96 \mathrm{~h}$ (Standards Methods, 1992) has now, however, become standard practice. Comparing $\mathrm{LC}_{50}$ results from Table 1 places $B$. harrisoni amoung the most sensitive of those organisms tested for chlorine. Gregg (1975, cited in US EPA, 1984) reported a $96 \mathrm{~h} \mathrm{LC}_{50}$ of $102 \mu \mathrm{g} / \mathrm{l}$ chlorine for the mayfly Stenonema ithaca. The $48 \mathrm{~h} \mathrm{LC}_{50}$ of $6.5 \mu \mathrm{g} / \mathrm{l}$ for Umbilo B. harrisoni and $5.0 \mu \mathrm{g} / \mathrm{l}$ for Westville $B$. harrisoni are considerably lower than the $48 \mathrm{~h} \mathrm{LC}_{50}$ of $357 \mu \mathrm{g} / \mathrm{l}$ for mayfly larvae of the genus Hexagenia (Ward and De Graeve, 1980). The discrepancy between these values seems absurd. However, it must be remembered that the toxicities of the various forms of chlorine are different (Hermanutz et al.,1990; DWAF, 1996) and in some of the literature it is not clear what form of chlorine was present, so comparisons of $\mathrm{LC}_{50}$ may be misleading. It is, therefore, necessary to clarify some points on chlorine toxicity. The products which result from the addition of chlorine to water can be grouped into four major categories:

- Free residual chlorine - the portion of chlorine injected into water remaining as molecular chlorine (hypochlorous acid $(\mathrm{HOCl})$, or hypochlorite ion $\left.\left(\mathrm{OCl}^{-}\right)\right)$

- Combined residual chlorine - the portion of the chlorine injected into water that combines with ammonia or nitrogenous compounds (chloramines).
- Total residual chlorine - the free residual chlorine plus the combined residual chlorine.

- Chlorine demand - the difference between the amount of chlorine injected into water and the total residual chlorine remaining at the end of a specified period. The actual substances produced are mostly chlorides.

The various chlorine residuals have different germicidal efficiencies and hence toxic effects on aquatic life. Free forms of chlorine are more toxic, with hypochlorous acid being the most effective germicide of all the chlorine residual fractions (Taylor, 1993) (Table 1). The combined forms of chlorine (chloramines) are slower to kill micro-organisms than free available chlorine, and it has been estimated that it would take about 25 times more combined available chlorine than free available chlorine to produce the same germicidal efficiency (White, 1992). The products which result from chlorine demand are to a large extent non-toxic chlorides (Mattice and Zittel, 1976). The differences in germicidal efficiencies of the various chlorine species may explain the large discrepancies in $\mathrm{LC}_{50} \mathrm{~s}$. In the case of Ward and De Graeve (1980) who were working with chlorine in domestic effluent, most of the chlorine would probably have been in the form of chloramine, as opposed to the present study in which the chlorine was in the form of free available chlorine.

The toxicity of a particular chemical agent is traditionally evaluated on the basis of tests carried out with healthy organisms. Test organisms that are in poor health or are stressed in some other manner, such as by previous or concurrent exposure to other toxicants are, however, likely to be more susceptible to a toxic 
chemical (Rand and Petrocelli, 1985). On the other hand organisms continually exposed to a certain chemical can build up tolerance and be less susceptible to that chemical. In this study, the health status of the test organisms prior to testing was not known. It was known that the Umbilo River was severely impacted by industrial effluent, but it was not known whether the $B$. harrisoni were hardy and tolerant of the polluted conditions or whether they were stressed and therefore more vulnerable to the test conditions. The comparative study with $B$. harrisoni from the clean Westville Stream yielded slightly different $\mathrm{LC}_{50}$ values, suggesting that the Umbilo B. harrisoni were possibly more tolerant of chlorine. The $96 \mathrm{~h}$ concentration response curves, however, suggested this difference was not significant as standard deviations of cumulative mortalities at specific chlorine concentrations overlapped.

It should also be borne in mind, however, that the type of experimental design used in this study does not suit the current regression analysis methods used in the US EPA Probit and Trimmed Spearman-Karber Programs. However at the time the experiments were conducted regression type experimental designs with many concentrations and low numbers of replicates were not as widely used as experimental designs consisting of many replicates and fewer treatments. In spite of this the results from these experiments can be considered relevant to South Africa's present attempts at setting meaningful Water Quality Guidelines.

The toxicity of chlorine to freshwater aquatic life is usually expressed as the concentration of total residual chlorine (TRC), and the US EPA states water quality criteria solely in these terms (Hermanutz et al., 1990). The US EPA freshwater criteria for protection of most aquatic species is $11 \mu \mathrm{g} / \mathrm{l} \mathrm{TRC}$ as a $96 \mathrm{~h}$ average. In South Africa the acute effect value (AEV) guideline is $5 \mu \mathrm{g} / \mathrm{l}$ TRC and $0.35 \mu \mathrm{g} / \mathrm{l}$ TRC for the chronic effect value (CEV). The proposed target water quality range (TWQR) is $0.2 \mu \mathrm{g} / \mathrm{l}$ TRC (DWAF, 1996). The AEV refers to the concentration at and above which a statistically significant acute adverse effect is expected to occur. It is not a target value or compliance concentration, but rather a danger or reaction level, indicating where acute adverse effects can be expected. Calculation of the AEV is primarily based on results of $96 \mathrm{~h}$ acute toxicity tests. The CEV refers to the highest concentration deemed safe for all or most populations even during continuous exposure. As the CEV is exceeded, the risk of ecosystem damage increases (Roux et al., 1996). Ninety percent of all readings at a site should be within the TWQR and all should be below the CEV (DWAF, 1996). The $\mathrm{LC}_{50}$ values for Umbilo and Westville $B$. harrisoni were $4.8 \mu \mathrm{g} / \mathrm{l}$ and $4.1 \mu \mathrm{g} / \mathrm{l}$ TRC respectively, which indicates that the AEV guideline of $5 \mu \mathrm{g} / \mathrm{l}$ TRC is at present the correct order of magnitude for the protection of riverine macroinvertebrate communities, but should be revised and refined as more data becomes available.

\section{Acknowledgements}

The authors wish to thank the National Research Foundation for funding, and the staff of Umgeni Water and the Institute for Water Research for advice and assistance.

\section{References}

BUIKEMA AL (Jr.), NIEDERLEHNER BR and CAIRNS J (Jr.) (1982) Biological Monitoring. Part IV - Toxicity Testing. Water Res. 16 239-262.

CHUTTER FM (1994) The rapid biological assessment of stream and river quality by means of the macroinvertebrate community in South Africa. In: Uys MC (ed.) Classification of Rivers and Environmental Health Indicators. Proceedings of a Joint South African Australian Workshop. WRC Report No TT 63/94.
CRASS RS (1947) Mayflies of Natal and the Eastern Cape. Ann. Natl. Mus. 11 37-110.

DEPARTMENT OF WATER AFFAIRS AND FORESTRY (DWAF) (1996) South African Water Quality Guidelines. Volume 7. Aquatic Ecosystems. Department of Water Affairs and Forestry, Private Bag X313, Pretoria, 0001, South Africa.

DALLAS HF and DAY JA (1993) The Effect of Water Quality Variables on Riverine Ecosystems: A Review. WRC Special Report, Project No 351, Box 824, Pretoria, 0001, South Africa.

DICKENS CW (1993) Personal communication. Senior Scientist, Umgeni Water.

DOHERTY FG, FARRIS JL, CHERRY DS and CAIRNS J (Jr.) (1986) Control of the freshwater fouling bivalve Corbicula fluminea by halogenation. Arch. Environ. Contam. Toxicol. 15 535-542.

FISHER DJ, BURTON DT, YONKOS LT, TURLEY SD and ZIEGLER GP (1999) The relative acute toxicity of continuous and intermittent exposures of chlorine and bromide to aquatic organisms in the presence and absence of ammonia. Water Res. 33 760-768.

HERMANUTZ RO, ALLEN KN and HEDTKE SF (1990) Toxicity and fate of total residual chlorine in outdoor experimental streams. In: Jolley RL, Condie LW, Johnson JD, Katz S, Minear RA, Mattice JS and Jacobs VA (eds.). Water Chlorination. Chemistry, Environmental Impact and Health Effects. Vol. 6. Lewis Publishers. 463-477.

JOHNSON JD and JOLLEY RL (1990) Water chlorination: The challenge. In: Jolley RL, Condie LW, Johnson JD, Katz S, Minear RA, Mattice JS and Jacobs VA (eds.) Water Chlorination. Chemistry, Environmental Impact and Health Effects. Vol. 6. Lewis Publishers. 21-27.

LAMBERTI GA and STEINMAN AD (1993) Research in artificial streams: applications, uses and abuses. J. N. Am. Benthol. Soc. 12 313-317.

MATTICE JS and ZITTEL HE (1976) Site specific evaluation of power plant chlorination. J. Water Pollut. Contr. Fed. 48 2284-2308.

MIDDAUGH DP, BECKHAM N, FOURNIE JW and DEARDORFF TL (1997) Evaluation of bleached kraft mill process water using Microtox ${ }^{\circledast}$, Ceriodaphnia dubia, and Menidia beryllina toxicity tests. Arch. Environ. Contam. Toxicol. 32 367-375.

PALMER CG, O'KEEFFE JH and PALMER AR (1993) Macroinvertebrate functional feeding groups in the middle and lower reaches of the Buffalo River, eastern Cape, South Africa. Part 2: Functional morphology and behaviour. Freshwater Biol. 29 455-462.

PALMER CG, GOETSCH PA and O'KEEFFE JH (1996) Development of a Recirculating Artificial Stream to Investigate the Use of Macroinvertebrates as Water Quality Indicators. WRC Report 475/1/96.

PALMER GC, WILLIAMS ML and GORDON AK (2003) Riverine macroinvertebrate responses to chlorine and chlorinated sewage effluents: Community structure in the Umsunduzi and Umbilo Rivers, KwaZulu Natal, South Africa. Water SA 29 (4) 473-481.

PARRISH PR (1985) Acute toxicity tests. In: Rand GM and Petrocelli S (eds.) Fundamentals of Aquatic Toxicology: Methods and Applications. Taylor and Francis, Washington.

PERSOONE GD and JANNSEN CR (1993) Freshwater invertebrate toxicity tests. In: Calow P(ed.) Handbook of Ecotoxicology. Blackwell Scientific Publications.

RAJAGOPAL S, NAIR KVK, VAN DER VELDE G and JENNER HA (1997) Response of mussel Brachidontes striatulus to chlorination and experimental study. Aquat. Toxicol. 39 135-149.

RAJAGOPAL S, VAN DER VELDE G, VAN DER GAAG $M$ and JENNER HA (2002) Laboratory evaluation of the toxicity of chlorine to the fouling hydroid Cordylophora caspia. Biofouling 18 55-64.

RAJAGOPAL S, VENUGOPALAN VP, VAN DER VELDE G and JENNER HA (2003) Tolerance of five species of tropical marine mussels to continuous chlorination. Mar. Environ. Res. 55 277-291.

RAND GM and PETROCELLI S (1985) Fundamentals of Aquatic Toxicology: Methods and Applications. Taylor and Francis, Washington.

ROUX DJ, JOOSE SHJ and MACKAY HM (1996) Substance-specific water quality criteria for the protection of South African freshwater ecosystems: Methods for derivation and initial results for some inorganic substances. S. Afr. J. Sci. 92 198-206.

STANDARD METHODS (1992) Standard Methods for the Examination of Water and Wastewater (18th edn.). American Public Health Association, Washington, DC. 
TAYLOR PA (1993) An evaluation of the toxicity of various forms of chlorine to Ceriodaphnia dubia. Environ. Toxicol. Chem. 12 925-930.

UNITED STATES ENVIRONMENTAL PROTECTION AGENCY (US EPA) (1984) Ambient Water Quality Criteria for Chlorine. EPA 440/ 5-84-030. National Technical Information Service, Springfield, VA.

VANDENHEUVEL MR, ELLIS RJ, TREMBLAY LA and STUTHRIDGE TR (2002) Exposure of reproductively maturing Rainbow trout to a New Zealand pulp and paper mill effluent. Ecotoxicol. Environ. Saf. 51 65-75.
WARD RW and DE GRAEVE GM (1978) Acute residual toxicity of several wastewater disinfectants to aquatic life. Water. Res. Bull. 14 696-709.

WARD RW and DE GRAEVE GM (1980) Acute toxicity of several disinfectants in domestic and industrial waste water. Water Res. Bull. 16 41-48.

WHITE GC (1992) The Handbook of Chlorination and Alternative Disinfectants ( $3^{\text {rd }}$ edn.) Van Nostrand Reinhold. New York.

WILLIAMS ML (1996) Macroinvertebrate Community and Species Responses to Chlorinated Sewage Effluent in the Usunduze and Umbilo Rivers, KwaZulu-Natal, South Africa. MSc Thesis, Rhodes Univ., South Africa. 